\title{
Evaluation of Nuclear Polyhedrosis Virus (NPV) and Emamectin Benzoate against Spodoptera litura (F.) (Lepidoptera: Noctuidae)
}

\author{
Muhammad Yasin ${ }^{1,2^{*}}$ (D) Muhammad Shoaib Qazi ${ }^{2}$, Waqas Wakil ${ }^{2,3^{*}}$ and Mirza Abdul Qayyum²,4
}

\begin{abstract}
The Oriental leaf worm moth, Spodoptera litura (F.) (Lepidoptera: Noctuidae), is among the most voracious insect pests in a variety of economically important crops, particularly cotton. It has developed resistance against conventional chemical insecticides. Therefore, it is vital to evaluate an integrated application of bio- and synthetic pesticide against this pest. Nuclear polyhedrosis virus (NPV) can be a potent alternative to control this pest. The present study was conducted to evaluate the efficacy of NPV and emamectin benzoate (Proclaim ${ }^{\circledR} 19 \mathrm{EC}$ ) against three geographically distinct populations of $\mathrm{S}$. litura in vitro conditions. Second and fourth larval instars were treated by three different concentrations of NPV (NPV-1 $2 \times 10^{9}, \mathrm{NPV}-23 \times 10^{9}$, and NPV-3 $4 \times 10^{9} \mathrm{POB} \mathrm{ml}{ }^{-1}$ ) and emamectin benzoate (EB $0.1 \mathrm{ppm}$ ) alone and in combination. The results showed that the highest mortality rate (83.28\%) was recorded for NPV-3 + EB, followed by NPV-2 + EB, NPV-1 + EB, EB, NPV-3, NPV-2, and NPV-3 at all the tests. Moreover, Faisalabad (FSD) population was found more susceptible, followed by Layyah (LY) and Multan (ML) populations. Reduction in pupation, adult emergence and egg eclosion was found directly related to the pathogenicity of the applied pathogens. The results of this study revealed that biorational control of $\mathrm{S}$. litura with combined application of NPV + emamectin benzoate was an effective tool.
\end{abstract}

Keywords: Nucleopolyhedrosis virus, Emamectin benzoate, Spodoptera litura, Efficacy

\section{Background}

The Oriental leaf worm moth, Spodoptera litura (F.) (Lepidoptera: Noctuidae) is a serious polyphagous and cosmopolitan insect pest of cash crops, vegetable and ornamentals (Senthil-Nathan and Kalaivani, 2005). In Pakistan, S. litura causes heavy losses in various regions such as the northern and southern districts of Punjab (Ahmad et al. 2007). The increase in area under cultivation of succulent crops like soybean, cotton, mung bean, cabbage, and vegetables provide ideal conditions for its vigorous reproduction, resulting in a rapid increase of

\footnotetext{
* Correspondence: yasin_1876@yahoo.com; waqaswakeel@hotmail.com 'College of Agriculture, BZU, Bahadur Sub-Campus, Layyah, Pakistan ${ }^{2}$ Department of Entomology, University of Agriculture, Faisalabad, Pakistan Full list of author information is available at the end of the article
}

generations and population size (Gao et al. 2004). Mainstay of the farming community to combat this pest is the use of synthetic chemical insecticides which not only cause serious harm to environment and human health but also develop resistance against these agents (Aydin and Gurkan, 2006). Indiscriminate use of these chemical has also led to resistance in S. litura population in different geographical areas of the Punjab (Pakistan) (Shad et al. 2012; Ahmad and Mehmood, 2015). This situation demands to evaluate safer eco-friendly alternatives.

Nucleopolyhedrosis viruses (NPVs) can be potent alternatives to the synthetic insecticides against $S$. litura (Ahmad et al. 2018). NPVs belong to family baculoviruses (BV), which is specific against a variety of insect pests of forests and economically important crops (Tang 
et al. 2011). This family comprises 600 viruses, including two genera, NPV and Granuloviruses (GV) (Hu et al. 2003). NPVs have great potentials against many lepidopterous pests (Tang et al. 2011 and Zhang et al. 2015).

Emamectin benzoate is a semi-synthetic derivative of abamectin which has been developed for the purpose of controlling variety of lepidopterous pests worldwide (Jansson et al. 1997). Moreover, new chemical insecticides have been established from natural sources; disturb the normal physiological functions of the targeted species (Thompson et al. 2000). Environmental Protection Agency (EPA) has classified emamectin benzoate as a reduced-risk compound due to environmentally benign characteristics (Saunders and Bret, 1997). It has both stomach and contact mode of actions, primarily acting on nicotinic acetylcholine receptor and subsequently on butyric acid receptors. Emamectin benzoate in contrast to synthetic insecticides, has low mammalian toxicity and exerts no toxic effect on non-target organisms. Due to strong mode of action, it is widely used against lepidopterous and dipterous insect pest (Stanley et al. 2006; Wang et al. 2013). In Pakistan, emamectin benzoate has been registered for the control of several species of Lepidoptera in field crops and vegetables.

Integration of synthetic insecticides with baculovirus enhances the efficacy of baculovirus, especially against S. litura (Arti and Yogita, 2014; Shaurub et al. 2014; Ayyub et al. 2019 Nawaz et al., 2019). Keeping in view the importance of low input based crop production and reduction of pesticides' load on the vegetable crops, the present study aimed to assess the efficacy of NPV alone and in combination with emamectin benzoate against 2nd and 4th larval instars of $S$. litura from various localities of Punjab (Pakistan) under laboratory conditions.

\section{Material and methods Insect culture}

Larvae of S. litura were collected from three different localities viz. Faisalabad (FSD), Multan (ML), and Layyah (LY), Pakistan and shifted to the Microbial Control Laboratory, Department of Entomology, University of Agriculture, Faisalabad. S. litura was mass cultured under the laboratory conditions at $26 \pm 2{ }^{\circ} \mathrm{C}, 70 \pm 5 \%$ relative humidity (R.H.) and a photoperiod of 12:12 (L:D) h on a semi artificial diet, following the method of Saljoqi et al. (2015). Adults of S. litura were fed on $10.0 \%$ honey solution and provided with a coarse surface of tissue as nappy liner to lay eggs.

\section{Insecticide used}

The commercial liquid formulation of Proclaim (Emamectin benzoate, $19 \mathrm{~g} \mathrm{l}^{-1}$, 19EC; Syngenta Pakistan, Ltd.,
Karachi, Pakistan) was used in the experiment. The insecticide was applied at $0.1 \mathrm{ppm}$.

\section{Viral isolation and suspension preparation}

NPV isolates were obtained from NPV-infected larvae stored in the Microbial Control Laboratory. The presence of NPV was confirmed by inverted microscope ( $x$ 40) with Giemsa staining (Yaman et al. 2001). Virus isolation and propagation were carried out in vivo as described by Monobrullah and Nagata (2000). Purified occlusion bodies (POBs $\mathrm{ml}^{-1}$ ) were counted five times, using a hemocytometer under inverted microscope. A dilution of various concentrations $\left(2 \times 10^{9} ; 3 \times 10^{9}\right.$; and $4 \times 10^{9} \mathrm{POBs} \mathrm{ml}^{-1}$ ) was prepared in distilled water from stock suspension (Cory and Myers, 2003).

\section{Bioassay}

Efficiency of emamectin benzoate and NPV was evaluated against 2nd and 4th larval instars. Both pathogens were applied, using a diet incorporation method. A diet piece of $0.5 \mathrm{~g}$ was offered to the larvae placed in glass vials $(7 \mathrm{~cm}$ height, $3 \mathrm{~cm}$ in diameter) (Qayyum et al. 2015). The artificial diet, mixed with the three concentrations of NPV $\left(2 \times 10^{9}, 3 \times 10^{9}\right.$, and $\left.4 \times 10^{9} \mathrm{POB} \mathrm{ml}^{-1}\right)$ and emamectin benzoate $(0.1 \mathrm{ppm})$ or a combined suspension of these was used. Each treatment contained 15 larvae (as a replicate), and was repeated thrice. Larvae were fed on the treated artificial diets for $48 \mathrm{~h}$. After 48 $h$, survivors were transferred into new vials containing non-treated fresh diet. Bioassay were conducted at $25 \pm$ $2{ }^{\circ} \mathrm{C}, 65 \pm 5 \%$ R.H. and a photoperiod of 14:10 (D:L) h in an incubator. Mortality rate was recorded every $24 \mathrm{~h}$ and the last count was recorded till pupation of both larval instars. The larvae were poked with a blunt needle and those unable to move in a coordinated manner were considered as dead (Ma et al. 2008; Qayyum et al. 2015). Pupation and adult emergence data were also recorded hereafter. The emerged adults were allowed to mate freely at each treatment and egg hatching percentage was calculated.

\section{Statistical analysis}

Mortality means were corrected using Abbott's formula (Abbott, 1925) and the data was subjected to one-way analysis of variance (ANOVA), using Minitab software (Minitab, 2002) and significance of means were separated by Tukey's HSD test at $1.0 \%$ significance level (Sokal and Rohlf, 1995).

\section{Results and discussion}

Efficacy of NPV and emamectin benzoate was challenged against 2nd and 4th larval instars of S. litura on the artificial diet and all treatments were found significant. Highest mortality was recorded for NPV-3 + EB, 
Table 1 Mean mortality $(\% \pm$ SE) of second and fourth larval instars of Spodoptera litura from three different field populations treated with nucleopolyhedrosis virus and emamectin benzoate (NPV-1 $2 \times 10^{9} \mathrm{POBs} \mathrm{ml} l^{-1}, \mathrm{NPV}-23 \times 10^{9} \mathrm{POBs} \mathrm{ml}{ }^{-1}, \mathrm{NPV}-33 \times 10^{9} \mathrm{POBs}$ $\mathrm{ml}^{-1}$, EM $\left.0.1 \mathrm{ppm}\right)$

\begin{tabular}{|c|c|c|c|c|c|c|}
\hline \multirow[t]{2}{*}{ Treatments } & \multicolumn{3}{|l|}{ Second instar } & \multicolumn{3}{|l|}{ Fourth instar } \\
\hline & FSD & LY & $\mathrm{ML}$ & FSD & LY & $\mathrm{ML}$ \\
\hline NPV-1 & $22.27 \pm 1.13 \mathrm{e}$ & $15.76 \pm 0.87 e$ & $13.38 \pm 0.92 \mathrm{ef}$ & $17.46 \pm 1.09 f$ & $12.80 \pm 0.86 f$ & $8.99 \pm 0.55 f$ \\
\hline NPV-2 & $35.66 \pm 1.55 d$ & $27.35 \pm 1.11 d$ & $20.31 \pm 1.14 \mathrm{e}$ & $28.21 \pm 1.61 \mathrm{ef}$ & $23.38 \pm 1.24 \mathrm{ef}$ & $16.45 \pm 1.03 e$ \\
\hline NPV-3 & $44.92 \pm 1.73 \mathrm{~cd}$ & $38.25 \pm 1.38 c$ & $31.79 \pm 1.50 \mathrm{de}$ & $39.79 \pm 1.59$ de & $32.43 \pm 1.43 \mathrm{de}$ & $25.50 \pm 1.20 d$ \\
\hline EM & $49.52 \pm 1.67 c$ & $42.64 \pm 1.57 c$ & $37.09 \pm 1.39 d$ & $44.42 \pm 1.70 d$ & $38.62 \pm 1.54 d$ & $30.74 \pm 1.37 d$ \\
\hline NPV-1 + EM & $68.83 \pm 2.12 b$ & $63.43 \pm 1.83 b c$ & $56.13 \pm 2.10 c$ & $62.27 \pm 2.67 c$ & $57.51 \pm 2.29 c$ & $50.31 \pm 2.06 c$ \\
\hline$N P V-2+E M$ & $89.84 \pm 2.70 a b$ & $81.42 \pm 2.61 b$ & $73.28 \pm 2.74 b$ & $80.72 \pm 3.80 b$ & $73.49 \pm 2.84 b$ & $66.82 \pm 2.24 b$ \\
\hline$N P V-3+E M$ & $100.00 \pm 0.00 a$ & $96.13 \pm 2.62 a$ & $87.93 \pm 2.82 a$ & $96.19 \pm 3.20 a$ & $88.41 \pm 3.20 a$ & $83.28 \pm 2.95 a$ \\
\hline
\end{tabular}

Mean sharing the same letters within each column are not significantly different at $1.0 \%$ level

followed by NPV-2 + EB, NPV-1 + EB, EB, NPV-3, NPV-2, and NPV-3 at all the tests. For 2nd instar larvae, the highest larval mortality rate $(49.52 \%)$ was recorded for emamectin benzoate in FSD population $\left(F_{7,71}=\right.$ $118.0, p \leq 0.01)$, followed by LY $\left(F_{7,71}=97.7, p \leq 0.01\right)$ and then $\operatorname{ML}\left(F_{7,71}=112, p \leq 0.01\right)$ populations (Table 1$)$. In the combined treatments, maximum larval mortality $(100.0 \%)$ was recorded at the highest concentration of NPV $\left(4 \times 10^{9} \mathrm{POB} \mathrm{ml}{ }^{-1}\right)$ and emamectin benzoate (0.1 ppm) (Table 1). In case of 4th instar larvae, significant differences were found among all the treatments. In individual applications, the highest larval mortality (44.42\%) was recorded for emamectin benzoate in FSD population $\left(F_{7,71}=128.0 ; p \leq 0.01\right)$, followed by LY $\left(F_{7,71}=87.6 ; p \leq 0.01\right)$ and then ML $\left(F_{7,71}=121 ; p \leq 0.01\right)$. Similarly, the highest mortality (96.19\%) was recorded in FSD population, followed by LY and ML populations for a high concentration of NPV $\left(4 \times 10^{9}\right.$ POB $\left.\mathrm{ml}^{-1}\right)$ with emamectin benzoate (0.01 ppm) (Table 1). With regard to proportion of insects succeeded to pupate (Table 2), the interaction of NPV and emamectin benzoate varied greatly and significantly.
The combined applications of microbial pathogens may enhance their pathogenicity, persistence and infection rate (Ali et al. 2016). Moreover, the issue of insecticide resistance can also be minimized as they exhibit novel modes of actions, which is lacking in conventional chemical insecticides (Qayyum et al. 2015 and Bala et al. 2018).

Combined action of both the two pathogens was proved to be more fatal than their sole application and lower proportion of pupation was observed for all populations (2nd instar: FSD $0.00 \pm 0.00$, LY $2.96 \pm 0.27$, ML $7.40 \pm 0.73$; 4th instar: FSD $3.70 \pm 0.37$, LY $8.88 \pm 0.71$, ML $13.33 \pm 0.96)$ than the control treatment (> 94.0\%). Larval mortality increased as the numbers of polyhedral occlusion bodies (POBs) were increased in individual or combined applications. Similar findings were reported by Nawaz et al. (2019) who reported a high mortality of Helicoverpa armigera $(\mathrm{H}$.) larvae with the increase of POBs number. Obtained results are also parallel to the findings of Arrizubieta et al. (2016), who reported the highest effectiveness of NPV and insecticides mixture against $H$. armigera. This might be attributed to the fact that the polyhedral bodies of NPV attach to the midget of host and multiply, thereby destroying the gut cells.

Table 2 Mean pupation (\% \pm SE) of second and fourth larval instars of Spodoptera litura from three different field populations treated with nucleopolyhedrosis virus and emamectin benzoate. (NPV-1 $2 \times 10^{9} \mathrm{POBs} \mathrm{ml}^{-1}, \mathrm{NPV}-23 \times 10^{9} \mathrm{POBs} \mathrm{ml}{ }^{-1}, \mathrm{NPV}-34 \times 10^{9}$ POBs $\left.\mathrm{ml}^{-1}, \mathrm{EM} 0.1 \mathrm{ppm}\right)$

\begin{tabular}{|c|c|c|c|c|c|c|}
\hline \multirow[t]{2}{*}{ Treatments } & \multicolumn{3}{|l|}{ Second instar } & \multicolumn{3}{|l|}{ Fourth instar } \\
\hline & $\overline{\mathrm{FSD}}$ & LY & $\mathrm{ML}$ & $\overline{\mathrm{FSD}}$ & LY & $\mathrm{ML}$ \\
\hline NPV-1 & $71.85 \pm 2.89 b$ & $79.25 \pm 2.59 b$ & $85.18 \pm 2.82 b$ & $78.51 \pm 2.85 b$ & $85.18 \pm 2.67 b$ & $91.11 \pm 3.22 \mathrm{ab}$ \\
\hline NPV-2 & $63.70 \pm 2.53 \mathrm{bc}$ & $68.14 \pm 2.27 b c$ & $76.29 \pm 2.56 b c$ & $69.63 \pm 1.95 b c$ & $74.07 \pm 2.50 \mathrm{bc}$ & $80.74 \pm 2.41 b$ \\
\hline NPV-3 & $51.85 \pm 2.34 c d$ & $59.25 \pm 2.19 \mathrm{~cd}$ & $65.18 \pm 1.88 \mathrm{~cd}$ & $58.51 \pm 1.67 c$ & $65.18 \pm 1.95 \mathrm{~cd}$ & $72.59 \pm 2.16 b c$ \\
\hline EM & $47.40 \pm 2.14 d$ & $54.81 \pm 1.35 d$ & $61.48 \pm 1.73 \mathrm{~cd}$ & $53.33 \pm 1.42 c$ & $60.74 \pm 1.71 d$ & $66.66 \pm 2.57 c$ \\
\hline$N P V-1+E M$ & $28.88 \pm 1.18 \mathrm{e}$ & $37.77 \pm 1.12 \mathrm{be}$ & $43.70 \pm 1.42 d$ & $34.81 \pm 1.25 d$ & $41.48 \pm 1.42 \mathrm{be}$ & $48.14 \pm 1.67 d$ \\
\hline$N P V-2+E M$ & $9.62 \pm 0.25 f$ & $16.29 \pm 0.96 f$ & $20.74 \pm 1.05 e$ & $17.77 \pm 0.98 \mathrm{e}$ & $25.18 \pm 1.15 f$ & $32.59 \pm 1.23 \mathrm{e}$ \\
\hline$N P V-3+E M$ & $0.00 \pm 0.00 \mathrm{~g}$ & $2.96 \pm 0.27 \mathrm{~g}$ & $7.40 \pm 0.73 f$ & $3.70 \pm 0.37 f$ & $8.88 \pm 0.71 \mathrm{~g}$ & $13.33 \pm 0.96 f$ \\
\hline Control & $94.81 \pm 2.97 a$ & $96.29 \pm 3.17 a$ & $97.03 \pm 3.04 a$ & $95.55 \pm 3.26 a$ & $97.03 \pm 2.98 a$ & $98.51 \pm 2.97 a$ \\
\hline
\end{tabular}


Table 3 Mean adult emergence (\% $\%$ SE) of second and fourth larval instars of Spodoptera litura from three different field populations treated with nucleopolyhedrosis virus and emamectin benzoate. (NPV-1 $2 \times 10^{9} \mathrm{POBs} \mathrm{ml}^{-1}, \mathrm{NPV}-23 \times 10^{9} \mathrm{POBs} \mathrm{ml}^{-1}, \mathrm{NPV}^{-3} 4 \times 10^{9}$ POBs $\mathrm{ml}^{-1}$, EM $0.1 \mathrm{ppm}$ )

\begin{tabular}{|c|c|c|c|c|c|c|}
\hline \multirow[t]{2}{*}{ Treatments } & \multicolumn{3}{|l|}{ Second instar } & \multicolumn{3}{|l|}{ Fourth instar } \\
\hline & $\overline{F S D}$ & LY & $\mathrm{ML}$ & $\overline{F S D}$ & LY & $\mathrm{ML}$ \\
\hline NPV-1 & $68.14 \pm 2.34 b$ & $75.55 \pm 1.92 b$ & $80.74 \pm 2.54 b$ & $74.81 \pm 2.48 b$ & $82.96 \pm 2.74 b$ & $87.40 \pm 2.73 a b$ \\
\hline NPV-2 & $57.77 \pm 2.48 b c$ & $63.70 \pm 1.45 c$ & $71.85 \pm 2.19 b c$ & $63.70 \pm 2.74 c$ & $71.85 \pm 2.94 b c$ & $76.29 \pm 1.96 b$ \\
\hline NPV-3 & $48.88 \pm 1.53 \mathrm{~cd}$ & $54.81 \pm 2.09 \mathrm{~cd}$ & $62.96 \pm 1.95 \mathrm{~cd}$ & $55.5 \pm 1.92 \mathrm{~cd}$ & $62.22 \pm 1.92 c$ & $67.46 \pm 1.52 \mathrm{bc}$ \\
\hline EM & $42.96 \pm 1.66 d$ & $51.85 \pm 1.48 \mathrm{~cd}$ & $58.51 \pm 1.67 \mathrm{~cd}$ & $47.40 \pm 1.82 d$ & $54.81 \pm 1.47 \mathrm{de}$ & $62.96 \pm 1.74 c$ \\
\hline NPV-1 + EM & $25.18 \pm 1.17 e$ & $32.59 \pm 1.25 d$ & $37.77 \pm 1.22 d$ & $31.85 \pm 1.15 \mathrm{e}$ & $36.29 \pm 1.24 \mathrm{e}$ & $45.28 \pm 1.25 d$ \\
\hline$N P V-2+E M$ & $6.66 \pm 0.22 f$ & $14.81 \pm 1.17 \mathrm{e}$ & $19.25 \pm 1.07 e$ & $12.59 \pm 0.54 f$ & $23.70 \pm 1.05 f$ & $27.40 \pm 1.13 \mathrm{e}$ \\
\hline$N P V-3+E M$ & $0.00 \pm 0.00 f$ & $1.48 \pm 0.17 f$ & $4.44 \pm 0.21 f$ & $0.00 \pm 0.00 \mathrm{~g}$ & $6.66 \pm 0.13 g$ & $9.62 \pm 0.39 f$ \\
\hline Control & $94.07 \pm 3.33 a$ & $95.55 \pm 3.11 a$ & $96.29 \pm 3.17 a$ & $94.81 \pm 3.85 a$ & $96.29 \pm 3.61 a$ & $97.77 \pm 3.11 a$ \\
\hline
\end{tabular}

Mean sharing the same letters within each column are not significantly different at 1.0\% level

The midgut is the first binding site of POBs, where they multiply and then infection transfer from cell to cell, causing the death of the host (Arif et al. 2018). In the present study, a high mortality rate was recorded in the combined treatments than in the sole application of NPV or emamectin benzoate. Additive or synergistic effects can be resulted by dual action of both pathogens, which may broaden the action spectrum. Similar findings were also reported (Qayyum et al. 2015; Ayyub et al. 2019 and Nawaz et al. 2019; Maqsood et al. 2019). Contrarily, Trang et al. (2002) reported antagonistic effects of NPV and imidacloprid. Antagonism may be caused due to reducing feeding or changing in $\mathrm{pH}$ of gut (El-Helaly and El-bendary 2013).

Apart from untreated larvae, the highest level of pupation (2nd instar: FSD $71.85 \pm 2.89$, LY $79.25 \pm 2.59$, ML $85.18 \pm 2.42$; 4th instar: FSD $78.51 \pm 1.85$, LY 85.18 \pm 2.67 , ML $91.11 \pm 3.22$ ) was observed in NPV1 treatment for both 2nd and 4th larval instars respectively (Table 2). Adult emergence and egg eclosion of both instars were found inversely related to pathogenicity of NPV and emamectin benzoate. Significant differences were observed at individual and combined treatments for all populations. Lowest adult emergence (2nd instar: FSD $0.00 \pm 0.00$, LY $1.48 \pm 0.17$, ML $4.44 \pm 0.21$; 4th instar: FSD $0.00 \pm 0.00$, LY $6.66 \pm 0.13$, ML $9.62 \pm 039$ ) and egg hatchability (2nd instar: FSD $0.00 \pm 0.00$, LY $0.00 \pm 0.00$, ML $2.93 \pm 0.09$; 4th instar: FSD $4.85 \pm$ 0.08 , LY $10.42 \pm 0.47$, ML $16.19 \pm 0.92$ ) was recorded in larvae treated with NPV-3 and EMB in 2nd and 4th instars, respectively, whereas the highest level was recorded in larvae treated with NPV-1. Overall, combined application exerted more hazardous effect on adult emergence and egg eclosion than the individual applications and was inversely proportional to the pathogenicity dependent manners (Tables 3 and 4). Similar findings were also observed by Qayyum et al. (2015) with Bacillus thuringiensis and NPV against $H$. armigera. Different susceptibility levels were observed in various populations. This might show the level of resistance in insects towards insecticides to which they have been exposed frequently and successively. Resistant populations (ML), frequently exposed to the insecticides, attained cross resistance against emamectin benzoate and vice versa.

Table 4 Mean egg eclosion (\% \pm SE) of second and fourth larval instars of Spodoptera litura from three different field populations treated with nucleopolyhedrosis virus and emamectin benzoate. (NPV-1 $2 \times 10^{9} \mathrm{POBs} \mathrm{ml}^{-1}, \mathrm{NPV}-23 \times 10^{9} \mathrm{POBs}^{-1}, \mathrm{NPV}^{-3} 4 \times 10^{9}$ POBs $\mathrm{ml}^{-1}$, EM $0.1 \mathrm{ppm}$ )

\begin{tabular}{|c|c|c|c|c|c|c|}
\hline \multirow[t]{2}{*}{ Treatments } & \multicolumn{3}{|l|}{ Second instar } & \multicolumn{3}{|l|}{ Fourth instar } \\
\hline & $\overline{F S D}$ & LY & $\mathrm{ML}$ & $\overline{\mathrm{FSD}}$ & LY & $\mathrm{ML}$ \\
\hline NPV-1 & $63.39 \pm 2.41 \mathrm{ab}$ & $70.61 \pm 2.47 b$ & $76.46 \pm 2.89 b$ & $74.45 \pm 1.35 a$ & $83.14 \pm 2.23 \mathrm{ab}$ & $89.48 \pm 2.40 a b$ \\
\hline NPV-2 & $51.91 \pm 2.17 b c$ & $62.58 \pm 2.09 c$ & $68.79 \pm 2.73 b c$ & $60.44 \pm 2.27 c$ & $72.39 \pm 2.15 b$ & $77.07 \pm 1.99 b c$ \\
\hline NPV-3 & $39.68 \pm 1.34 c$ & $47.10 \pm 1.58 d$ & $51.02 \pm 1.93 c$ & $45.08 \pm 1.58 d$ & $54.91 \pm 1.42 c$ & $63.20 \pm 2.29 c$ \\
\hline EM & $27.28 \pm 1.21 \mathrm{~cd}$ & $38.50 \pm 1.31 \mathrm{e}$ & $42.25 \pm 1.25 \mathrm{~cd}$ & $32.59 \pm 1.25 \mathrm{e}$ & $43.95 \pm 1.30 \mathrm{~cd}$ & $52.58 \pm 1.60 \mathrm{~cd}$ \\
\hline$N P V-1+E M$ & $18.49 \pm 1.03 d$ & $27.47 \pm 1.12 f$ & $35.96 \pm 1.39 d$ & $25.15 \pm 1.09 \mathrm{ef}$ & $36.41 \pm 1.23 d$ & $41.25 \pm 1.42 d$ \\
\hline$N P V-2+E M$ & $11.45 \pm 0.22 \mathrm{e}$ & $18.40 \pm 1.01 \mathrm{~g}$ & $21.18 \pm 1.14 \mathrm{e}$ & $18.22 \pm 0.48 f$ & $24.05 \pm 1.11 \mathrm{e}$ & $33.28 \pm 1.19 \mathrm{de}$ \\
\hline$N P V-3+E M$ & $0.00 \pm 0.00 f$ & $0.00 \pm 0.00 \mathrm{~h}$ & $2.93 \pm 0.09 f$ & $4.85 \pm 0.08 \mathrm{~g}$ & $10.42 \pm 0.47 f$ & $16.19 \pm 0.92 f$ \\
\hline Control & $83.37 \pm 2.63 a$ & $90.63 \pm 3.61 a$ & $92.39 \pm 2.82 \mathrm{a}$ & $92.74 \pm 3.39 a$ & $93.89 \pm 2.92 \mathrm{a}$ & $95.38 \pm 3.23 a$ \\
\hline
\end{tabular}




\section{Conclusion}

Integration of NPV and emamectin benzoate could be effectively used against the notorious pest ( $S$. litura). Both of the two pathogens represented better tools to combat resistance related issues. Further evaluations under field conditions is needed for further validation.

\section{Acknowledgements}

We are obliged to Dr. Ahmad Nawaz (College of Agriculture, BZU Bahadur Sub-Campus, Layyah) for his valuable suggestions in MS.

\section{Authors' contributions}

All authors equally participated in this study. WW conceived and designed the study. MSQ and MY conducted the research and prepared first draft. MAQ performed statistical analysis and prepared graphs. WW supervised, reviewed and edited MS for final submission. The author(s) read and approved the final manuscript.

\section{Funding}

N/A

\section{Availability of data and materials}

The datasets used and/or analyzed during the current study are available from the corresponding authors on request.

\section{Ethics approval and consent to participate}

Not applicable

\section{Consent for publication}

All authors are agreed to publish this MS and it has not been submitted in any other journal.

\section{Competing interests}

The authors declare that they have no competing interests.

\section{Author details}

${ }^{1}$ College of Agriculture, BZU, Bahadur Sub-Campus, Layyah, Pakistan. ${ }^{2}$ Department of Entomology, University of Agriculture, Faisalabad, Pakistan. ${ }^{3}$ Department of Continuing Education, University of Agriculture, Faisalabad, Pakistan. ${ }^{4}$ Department of Entomology, MNS University of Agriculture, Multan, Pakistan.

Received: 12 February 2020 Accepted: 25 May 2020

Published online: 07 July 2020

\section{References}

Abbott WS (1925) A method of computing the effectiveness of an insecticide. J Econ Entomol 18:265-267

Ahmad JN, Mushtaq R, Ahmad SJN, Maqsood S, Ahuja I, Bones AM (2018) Molecular identification and pathological characteristics of NPV isolated from Spodoptera litura (Fabricius) in Pakistan. Pak J Zool 50:2229-2237

Ahmad M, Arif Ml, Ahmad M (2007) Occurrence of insecticide resistance in field populations of Spodoptera litura (Lepidoptera: Noctuidae) in Pakistan. Crop Prot 26:809-817

Ahmad M, Mehmood R (2015) Monitoring of resistance to new chemistry insecticides in Spodoptera litura (Lepidoptera: Noctuidae) in Pakistan. J Econ Entomol 108(3):1279-1288

Ali H, Hou Y, Tang B, Shi Z, Muhammad A, Sanda NB (2016) A way of reproductive manipulation and biology of Wolbachia pipientis. J Exp Biol Agric Sci 4(2):156-168

Arif M, Islam SU, Adnan M, Anwar M, Ali H, Wu Z (2018) Recent progress on gene silencing/suppression by virus-derived small interfering RNAs in rice viruses especially Rice grassy stunt virus. Microb Pathog 125:210-218

Arrizubieta M, Simón O, Torres-Vila LM, Figueiredo E, Mendiola J, Mexia A, Caballero P, Williams T (2016) Insecticidal efficacy and persistence of a cooccluded binary mixture of Helicoverpa armigera n0ucleopolyhedro virus (Hear NPV) variants in protected and field-grown tomato crops on the Iberian Peninsula. Pest Manag Sci 72(4):660-670
Arti P, Yogita W (2014) Field compatibility of microbial pesticide SL NPV with synthetic pesticide Roket, Cypermethrin + Profenofos] against tobacco caterpillar Spodoptera litura [Fabricus]. Res J Pharm Biol Chem Sci (2)4:767

Aydin MH, Gurkan MO (2006) The efficacy of Spinosad on different strains of Spodoptera littoralis (Boisduval) (Lepidoptera: Noctuidae). Turkish J Biol 30:5-9

Ayyub MB, Nawaz A, Arif MJ, Amrao L (2019) Individual and combined impact of nuclear polyhedrosis virus and spinosad to control the tropical armyworm, Spodoptera litura (Fabricius) (Lepidoptera: Noctuidae), in cotton in Pakistan. Egypt J Biol Pest Control 29(67):1-6

Bala NS, Muhammad A, Ali H, Hou Y (2018) Entomopathogenic nematode Steinernema carpocapsae surpasses the cellular immune responses of the hispid beetle, Octodonta nipae (Coleoptera: Chrysomelidae). Microb Pathog 124:337-345

Cory JS, Myers JH (2003) The ecology and evolution of insect baculoviruses. Annu Rev Ecol Evol Syst 34:239-272

El-Helaly AA, El-bendary HM (2013) Impact of Spinosad and Nucleopolyhedrosis virus alone and in combination against the cotton leaf worm Spodoptera littoralis under laboratory. App Sci Rep 2(1):17-21

Gao C, Bei Y, Chen T, Gu X (2004) On factors causing outbreak of Spodoptera litura (Fabricius). Acta Agri Zhejiangensis 16:332-335

Hu Z, Chen X, Sun X (2003) Molecular Biology of Insect Viruses. A review. Adv Microb Control Insect Pests:83-107

Jansson RK, Peterson RF, Mookerjee PK, Halliday WR, Argentine JA, Dybas RA (1997) Development of a novel soluble granule formulation of emamectin benzoate for control of Lepidopterous pests. Flo Entomol 80:425-442

Ma X, Liu X, Ning X, Zhang B, Han F, Guan X, Tan Y, Zhang Q (2008) Effects of Bacillus thuringiensis toxin Cry1Ac and Beauveria bassiana on Asiatic corn borer (Lepidoptera: Crambidae). J Invert Pathol 99:123-128

Maqsood S, Afzal M, Haider MS, Khan HAA, Ali M, Ashfaq M, Aqueel MA, Ullah M (2019) Effectiveness of uuclear polyhedrosis virus and Bacillus thuringiensis alone and in combination against Spodoptera litura (Fabricius). Pak J Zool 51(2):631-641

Minitab (2002) Software Inc. Northampton, MA, USA

Monobrullah M, Nagata M (2000) Effects of larval age on susceptibility of Spodoptera litura (Lepidoptera: Noctuidae) to Spodoptera litura multiple nuclear polyhedrosis virus. Can Entomol 132:337-340

Nawaz A, Ali H, Sufyan M, Gogi MD, Arif MJ, Ranjha MH, Arshid M, Waseem M, Mustafa T, Oasim M, Rizwan M, Zaynab M, Khan KA, Ghramh HA (2019) Comparative bio-efficacy of nuclear polyhedrosis virus (NPV) and Spinosad against American boll worm, Helicoverpa armigera (Hubner). Rev Brasil de Entomol 63:277-282

Qayyum MA, Wakil W, Arif MJ, Sahi ST (2015) Bacillus thuringiensis and Nuclear Polyhedrosis Virus for the Enhanced Bio-control of Helicoverpa armigera. Int J Agric Biol 17(5):1043-1048

Saljoqi A, Haq R, Ehsan-ul-Haq KJ, Ali G (2015) Rearing of Spodoptera litura (Fabricius) on different artificial diets and its parasitization with Trichogramma chilonis (Ishii). Pak J Zool 47(1):169-175

Saunders DG, Bret BL (1997) Fate of spinosad in the environment. Down to Earth 52:14-20

Senthil-Nathan S, Kalaivanic K (2005) Efficacy of nucleopolyhedrovirus and Azadiractin on Spodoptera litura Fabricius (Lepidoptera: Noctuidae). Biol Control 34(1):93-98

Shad SA, Sayyed AH, Fazal S, Saleem MA, Zaka SM, Ali M (2012) Field evolved resistance to carbamates, organophosphates, pyrethroids, and new chemistry insecticides in Spodoptera litura Fab. (Lepidoptera: Noctuidae). J Pest Sci 85: 153-162

Shaurub EH, El-Meguid AA, Abd El-Aziz NM (2014) Effect of individual and combined treatment with Azadirachtin and Spodoptera littoralis Multicapsid Nucleopolyhedrovirus (SpliMNPV, Baculoviridae) on the Egyptian Cotton Leaf worm Spodoptera littoralis (Boisduval) (Lepidoptera: Noctuidae). Ecol Balk 6(2): 93-100

Sokal R, Rohlf FJ (1995) Biometry, 3rd edn. Freeman and Company, New York, USA

Stanley J, Chandrasekaran S, Regupathy A, Sheeba-Jasmine R (2006) Base line toxicity of emamectin and spinosad to Spodoptera litura. Ann Plant Protect Sci 14:346-349

Tanga XX, Sun XL, Pub GQ, Wang WB, Zhang CX, Zhua J (2011) Expression of a neurotoxin gene improves the insecticidal activity of Spodoptera litura nucleopolyhedrovirus (SpltNPV). Virus Res 159(1):51-56

Thompson GD, Dutton R, Sparks TC (2000) Spinosad a case study: an example from a natural products discovery programme. Pest Manag Sci 56:696-702 
Trang T, Kieu T, Chaudhari S (2002) Bioassay of nuclear polyhydrosis virus (NPV) and in combination with insecticide on Spodeptera litura (Fab). Omerica 10: 45-53

Wang D, Wang YM, Liu HY, Xin Z, Xue M (2013) Lethal and sublethal effects of Spinosad on Spodoptera exigua (Lepidoptera: Noctuidae). J Econ Entomol 106(4):1825-1831

Yaman M, Nalçacioğlu R, Demirbağ Z (2001) Viral control of the European pine sawfly, Neodiprion sertifer (Geoffroy) in Turkey. Turk J Biol 25:419-425

Zhang S, Wu F, Li Z, Lu Z, Zhang X, Zhang Q, Liu X (2015) Effects of nucleopolyhedrovirus infection on the development of Helicoverpa armigera (Lepidoptera: Noctuidae) and expression of its 20-hydroxyecdysone and juvenile hormone related genes. Fl Entomol 98(2):682-689

\section{Publisher's Note}

Springer Nature remains neutral with regard to jurisdictional claims in published maps and institutional affiliations.

\section{Submit your manuscript to a SpringerOpen ${ }^{\circ}$ journal and benefit from:}

- Convenient online submission

Rigorous peer review

- Open access: articles freely available online

High visibility within the field

- Retaining the copyright to your article

Submit your next manuscript at $\boldsymbol{\nabla}$ springeropen.com 